\title{
Impoverishment assessment of slum dwellers after off-site and on-site resettlement: a case of Indore
}

Commonwealth Journal of Local Governance

Issue 15: June 2014

http://epress.lib.uts.edu.au/ojs/index.php/cjlg

\section{Sejal Patel}

(CEPT) University

Ahmedabad, India

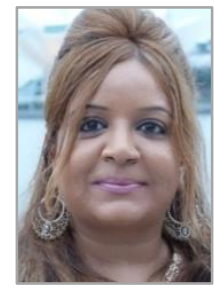

\section{Ritika Mandhyan}

(CEPT) University

Ahmedabad, India

\section{Abstract}

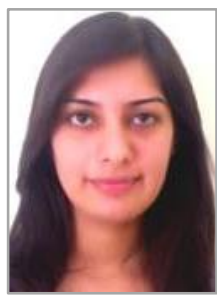

This paper is an attempt to assess the impacts of off-site and on-site resettlement projects in Indore by comparing slum dwellers lives before and after the implementation of the projects, complimenting and corroborating a sister paper based on fieldwork in Ahmedabad (Patel, Sliuzas, Mathur, \& Miscione, fortcoming). The impact analysis is based on the indicators of impoverishment risks due to displacement and resettlement formulated by Cernea (2000a) in his Impoverishment Risks and Reconstruction (IRR) model. The findings indicates the presence of the following forms of impoverishment which Cernea proposed for the displacees: significant loss in household assets, increased joblessness or unemployment, loss of access to common services, increased health risks, marginalisation and social disarticulation, all of which have compounded their vulnerability and chances of falling deeper into poverty. The paper also argues that compared to off-site and on-site resettlement displacees were less affected by negative consequences and impoverishment risks. The paper concludes with recommendations for slum resettlement policies of local government so that impoverishment risks can be reasonably averted.

Key words: Relocation, rehabilitation slums, impoverishmentrisk, development induced displacement and resettlemen

\section{Introduction}

Slum improvement has increasingly become a priority for state and local governments in India. Various interventions in terms of policies and programmes have been undertaken to upgrade present slums and prevent future slums. The policies of slums have graduated from the eviction of slums to relocation and rehabilitation ${ }^{1}$, emerging from the new thoughts that consider providing more than a mere house to the displaced slum dwellers. Yet the slum policies are inefficient in addressing overall wellbeing of the displaced slum dwellers and pose impoverishment risks for many of them.

\footnotetext{
${ }^{1}$ According to Asian Development Bank (ADB), rebuilding of the houses, assets (which include productive land) and infrastructure in another location is 'relocation'and re-establishment of incomes, livelihood assets, social system is 'rehabilitation' (ADB 1998a, ADB 1998b, Hasan 2006 as quoted by (Kabir, 2011)).
} 
Impoverishment refers to situations in which people's welfare and livelihood worsen as a result of a specific intervention. Risk is defined as the possibility embedded in a certain course of social action to trigger adverse effects such as losses, destruction, functionally counterproductive impacts, deprivations of future generations, etc. This paper attempts to assess the impoverishment risks caused due to displacement and resettlement ${ }^{2}$ under the Basic Services for the Urban Poor (BSUP) ${ }^{3}$ programme of Jawaharlal Nehru National Urban Renewal Mission (JNNURM) launched by Government of India in 2007. JNNURM is the single largest infusion of public funds to urban local governments for transport and other infrastructure. Within this Mission, the Ministry of Urban Development, Housing and Poverty Alleviation (MoUDH\&PA) focuses both on performance-linked infrastructure investment in Urban Local Bodies (ULB) through its Urban Infrastructure and Governance (UIG) programme, and on integrated development of slums in ULBs through provision of shelter and basic services through the Basic Services for the Urban Poor (BSUP) programme. Thus JNNURM, through UIG and BSUP presents a two pronged approach which on one hand envisions rapid economic growth through large scale infrastructure projects and on the other, inclusion of the urban poor in the economic growth story.

However, the UIG-financed infrastructure projects, in most of the JNNURM listed cities of India, have led to large scale displacement of urban poor residents along with a loss of livelihoods, social networks and access to amenities. Displacements due to 'developmental' projects raise questions about distribution of the benefits of development. Critics of development-induced-displacement have demonstrated that the displacees endure substantial risks of social, economic and cultural impoverishments and thereby raise issues of social justice and equity (Cernea, 2000a, b;Downing, 1996). Nevertheless, in most cases the government rationalises these concerns by claiming 'greater benefits for larger number' and by claiming to rehabilitate the displacees to prior levels of wellbeing to justify the ills of displacement.

In most cities of India, BSUP projects are mainly designed as relocation to new housing estates in the urban periphery rather than in situ up-gradation of basic services as claimed in the BSUP policy rhetoric. The displacement of the 'eligible' slum dwellers from prime urban locations to the periphery comes at considerable economic, social and human costs and the 'ineligible', which are unacknowledged and abandoned are even worse off (Patel, et al., 2013).

\footnotetext{
${ }^{2}$ Global Land Tool Network (GLTN), UN-HABITAT defined 'relocation' and 'resettlement' separately. According to them 'relocation' is the transfer of individual or group of people physically from their original place to another place,temporarily or permanently. They defined'resettlement' as provision of basic needs in the place of relocation or in the place of their origin on their return (in case of on-site resettlement). The basic needs include shelter, basic infrastructure, services, livelihood opportunities and tenure security.(UN-HABITAT,2010) With their definition they also drew attention to different types of resettlement like voluntary or involuntary resettlement, resettlement due to natural disaster, resettlement in another location or on-site resettlement.

${ }^{3}$ BSUPisoneofthesub-missionsof Jawharlal Nehru National Urban Renewal Mission (JNNURM) which has been launched by the Govt. of India. The programme focuses attention to the urban poor of the 63 designated mission cities in the country.
} 
In the case of off-site or on-site resettlement, only few attain better living conditions whereas the majority are made worse off due to additional financial responsibilities, insecurity and poor community interaction. The latter cannot be ignored (Cernea \& Kanbur, 2002). In both processes, whether off-site or on-site resettlement, the displaced slum dwellers in Indian cities are inevitably exposed to multiple impoverishments (Patel, et al., 2013).

The forms of impoverishments risks for displacees proposed by Cernea, (2000b) in his Impoverishment Risks and Reconstruction (IRR) model include landlessness, homelessness, joblessness, loss of access to common property resources, marginalisation, food insecurity, morbidity and mortality, and social disarticulation. In the past three decades, these interlinked impoverishment forms emerging in the displacees have been empirically reconfirmed, and evidence also includes a major World Bank review (World Bank, 1994). But these studies are largely in the context of rural displacements. Urban development-induced displacement and its consequences on the displacees, however, remains a relatively unstudied topic (Bartolome, 1993). It is projected that the infrastructure projects under JNNURM will increasingly account for major displacements in the cities of India and therefore the outcomes and impacts of the implemented projects demand more focus on the rhetoric of BSUP policy, and practice by local governments adopted under such projects. In the Indian context also, impacts of displacement and resettlement of the urban poor in fast-urbanising cities remains a largely under-explored topic with the exception of a few authors. For example, Patel. et al. 2013 and Bahn, 2009 have shown evidence of the consequences of displacement and resttlement on the urban poor. This study attempts to bridge this research gap and adds empirical evidence to research by the lead author in a different empirical setting i.e Ahmedabad (Patel, et al., 2013) by studying Development Induced Displacement and Resettlement (DIDR) of the urban poor in Indore. The aim of this study is to assess impoverishment risks due to displacement and resettlement of the urban poor under BSUP projects in Indore.

The city of Indore with approximately two million population(Census, $2011^{4}$ )is the largest city in the state of Madhya Pradesh in central India and is the $14^{\text {th }}$ most populous city in India. As per the 2001 Census, the slum population of Indore constituted $16.25 \%$ of the total population while the population in slums notified by the Madhya Pradesh Slum Clearance and Improvement Act constituted 20\% of the total population. Several initiatives and intervention have been made by the state and local government to upgrade slums in Indore, starting from the Madhya Pradesh Nagariya Kshetron ke Bhoomihin Vyakti Adhiniyam 1984 popularly known as ${ }^{\text {Patta' }}$ Act ${ }^{5}$ to the Slum Rehabilitation and Relocation Scheme $e^{6}$ under BSUP.

\footnotetext{
${ }^{4}$ City population of $1,960,631$ and urban aglomoration of $2,167,447$, compared to a city opulation $1,474,968$ urban aglomoration of 1,516,918 at the 2001 census. See also http://censusmp.nic.in/censusmp/All-

PDF/3Trendsinurbanization21.12.2011.pdf

${ }^{5}$ The Madhya Pradesh Nagariya Kshetron Ke Bhoomihin Vyakti (Pattadhruti Adhikaron Ka Pradan Kiya Jana) Adhiniyam, 1984, popularly known as the 'Patta' Act ('Leasehold Land rights' Act) was introduced to grant leasehold rights to the
} 


\section{Methodology}

This study is based on mixed methods i.e. predominatly qualitative data supported by quantitative data for the two selected case studies.In Indore, under BSUP, 12 project sites have been finalised under two distinct categories i.e off-site and on-site resettlement. Of these, 10 sites are a case of offsite resettlement and two sites are a case of on-site resettlement. In the latter category, eligibile slum dwellers are provided interim housing on a part of the cleared slum site, and on completion of construction, are resettled in dwelling units on the same site. For this research two case studies were taken, one from each category i.e off-site and on-site resettlement. These two case studies were considered because they were the first completed BSUP projects under each category and the displacees were residing on the sites for at least two years at the time of research and hence the resettlement process had gained sufficient maturity from which to draw ineferences.

The two case studies include: a) Scheme no. 134, where 272 households displaced due to infrastructure projects under JNNURM were allotted dwelling units, but only 180 households were actually residing and b) Panchsheel Nagar, where 300 households were resettled on-site, after residing in interim housing on the same site for an average of three years. This study is limited by certain factors. First, the process by which slum relocation and resettlement takes place is a complex, lengthy process spanning several years and involving complex approvals, financing, planning, and finally construction. Fieldwork for this research was confined to ten weeks. Consequently, given the time constraint, the research was narrowed to focus only on the negative consequences and impoverishment risks of the displacees post resettlement.

Second, the study is more of a qualitative research study supported by quantitative data and is predoinantly from the perspective of the displacees. The comparison between the lives of displacees before and after resettlement in the new dwelling unit was captured quantitatively and qualitatively in the questionnaire based on the recall of the residents. The recall of quantitative data such as distance, income etc. was traingulated through other means. For instance the distance to school in kilometers recalled by a respondent was corroborated by mapping the route between the earlier residence and the earlier school. The recall of qualitative data such as community bonding, feelings of inclusion etc. was solely based on memory and hence has the limitations related to recall such as memory decayed or contaminated (Gass \& Mackey, 2013).

\footnotetext{
landless persons occupying urban lands. The Act was amended in 1998 to extend the cutoff date of eligibility to 31 st May 1998. Under the 'Patta' Act, three categories of pattas are given, category 'ka' (A) for the registration of disputed cases, category 'kha'(B)forpermanentleaseof30 years and category 'gha' (C) for temporary lease of one year (CDP-Indore, 2006).

${ }^{6}$ Indore Municipal Corporation (IMC) proposed to take up Slum and poor locality integrated area development with the clear and limited objectives: to provide security of tenure, to integrate the slums with the social networks and economic structure of the city, to transform the physical infrastructure especially water and sanitation. Sustainable improvement in standards of health, education and community life and increased income-earning potential of people in slum's of Indore, sustainable improvement in overall quality of life of people living in slums, to facilitate the grassroots community participation in the spirit of the 74th Amendment to the Constitution through appropriate legal, financial and organizational framework. Strong, committed and broad-based formal and informal community-based groups, which participate actively in sustainable development activities established and functioning and to strengthen local government to ensure that assets created are property maintained and project benefits sustained (Mehta \& Associates, 2006).
} 
Figure 1: Location of selected sites and slums in Indore ${ }^{7}$

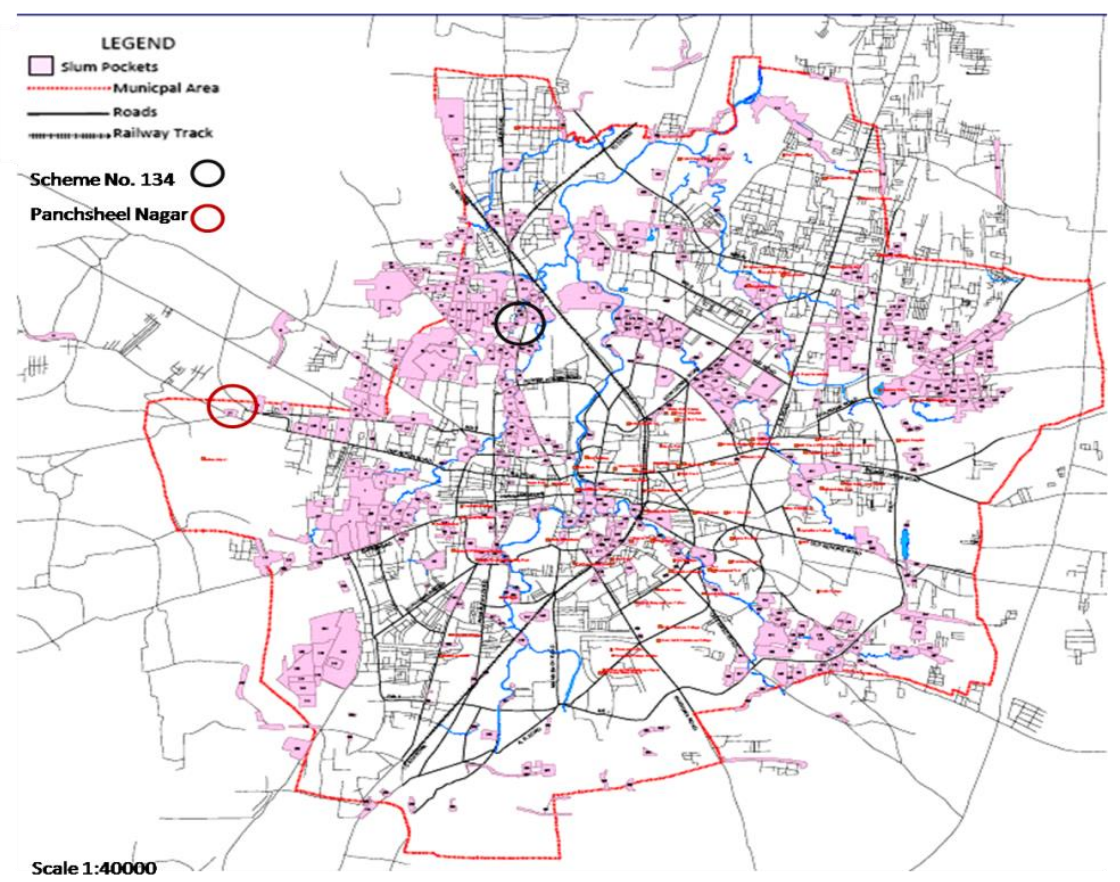

The study used primary data collected through questionnaire survey and interviews and observations from seventy five households (25\% of 300 households) in Panchsheel Nagar and fourty five households (25\% of 180 households) in Scheme no. 134 [Table1] using stratified random sampling. The secondary data included documents collected from Indore Municipal Corporation (IMC), Indore Development Authority (IDA) office and the JNNURM project office. Internal reports from consultants of the project and interaction with the community leaders were also an important data source for this study.

The interviews followed a set of questions derived from documentary analysis related to the case. The objective of the interviews was to corroborate findings from the questionnaire survey and to discover new information about the issues related to the life of slum dwellers after resettlement. The questionnaire was formulated to capture aspects of a household before and after resettlement such as household details, income and expenditure patterns, health and hygiene, education, social networks, marginalisation, food security, loss due to relocation, productivity in terms of time utilised at work, education etc.,access to services, social disarticulation, kinship scatteredness, et call of which would lead to inferences on social and economic impoverishment of respondents.

${ }^{7}$ Source: Indore Municipal Corporation 
Table 1: Number of dwelling units and sample distribution in each case study

\begin{tabular}{|c|c|c|c|c|}
\hline Site & $\begin{array}{l}\text { Dwellings / Plots } \\
\text { constructed }\end{array}$ & $\begin{array}{l}\text { Dwellings } \\
\text { allocated }\end{array}$ & $\begin{array}{l}\text { Dwellings } \\
\text { occupied }\end{array}$ & $\begin{array}{l}\text { Sample } \\
\text { No.(25\%) }\end{array}$ \\
\hline Resettlement on BSUP site & 544 & 300 & 300 & 75 \\
\hline $\begin{array}{c}\text { Panchsheel Nagar(Insitu } \\
\text { Resettlement) }\end{array}$ & 640 & 272 & 180 & 45 \\
\hline $\begin{array}{c}\text { Scheme No. 134 (off site } \\
\text { Resettlement) }\end{array}$ & 1184 & 572 & 480 & 120 \\
\hline Sub Total &
\end{tabular}

\section{Impoverishment risks due to off-site and on site resettlement}

Development Induced Displacement and Resettlement (DIDR) aims at generating economic growth, and improve general welfare (Oliver-Smith, 2009).However, displacees always experience trauma and hardships in re-establishing their livelihoods and social, community ties in new site (Oliver-Smith, 2009).Pertaining to DIDR,Cernea, (1996, 2006 and 2008)developed the Impoverishment Risks and Reconstruction (IRR) model comprising economic, cultural and social impoverishments in order to enable the implementing authority to prevent impoverishment of the displacees.

The following have been identified by Cernea (1996, 2006 and 2008)as major risks of impoverishment resulting from involuntary displacement: landlessness, joblessness, homelessness, marginalisation, loss of common property resources, increased health risks, food insecurity, and social disarticulation. These risks may not occur in all resettlement projects, their importance relative to each other may change, and a specific resettlement project may yield other significant risks (Hoadley, 2004).It is likely that a number of these risks will be present at the same time. The actualisation of the risks means that a community is pushed deeper into poverty and crisis by the loss, simultaneously, of economic, social and cultural resources. Of these loss of land is the most visible risk, but may account for only 10-20\% of the impoverishment risk(Downing, 2002).Unless the risks associated with resettlement are identified, assessed and addressed in the resettlement policy, resettlement can erode a community's access to the elements needed for rehabilitation and sustainability i.e social, human, physical and natural capital. Deeper impoverishment will also expose resettlers to the loss of civil and human rights, and, being poor, they are less able to demand these rights(Hoadley, 2004).

Cernea's impoverishment risks, largely applied in rural displacement, have been reinterpreted to suit the urban context of Indore and accordingly have been detailed out as specific indicators under each risk as shown in Table 2. 
Table 2: List of redefined parameters for analysing the life of slum dwellers after resettlement

\begin{tabular}{|c|c|c|c|c|c|c|c|}
\hline \multicolumn{8}{|l|}{$\begin{array}{l}\text { Landlessness: Lo } \\
\text { livelihood, social at } \\
\text { Joblessness }\end{array}$} \\
\hline \multicolumn{2}{|l|}{ Loss of Job } & Loss of Assets & \multicolumn{2}{|c|}{ Change in Occupation } & \multicolumn{3}{|c|}{ Additional financial burden } \\
\hline \multicolumn{8}{|c|}{$\begin{array}{l}\text { Additional financial burden in terms of Equated Monthly Installment (EMI) paid, increased transport costs } \\
\text { health costs, cost of services like electricity, water etc. }\end{array}$} \\
\hline \multicolumn{8}{|c|}{ Homelessness } \\
\hline \multicolumn{2}{|c|}{ Loss of dwelling/shelter } & \multicolumn{2}{|c|}{ Inappropriate replacement } & \multicolumn{4}{|c|}{$\begin{array}{l}\text { Loss of groups cultural space resulting in the } \\
\text { sense of placelessness }\end{array}$} \\
\hline \multicolumn{8}{|l|}{ Marginalisation } \\
\hline $\begin{array}{l}\text { Lower socio-eco } \\
\text { status in new } \\
\text { location }\end{array}$ & \multicolumn{2}{|c|}{$\begin{array}{l}\text { Los of political power in } \\
\text { new societal structure }\end{array}$} & \multicolumn{3}{|c|}{$\begin{array}{c}\text { Inappropriate skills in new } \\
\text { location loss of human capital }\end{array}$} & \begin{tabular}{c|} 
Loss of \\
economic power
\end{tabular} & $\begin{array}{l}\text { Loss of } \\
\text { standing in } \\
\text { community }\end{array}$ \\
\hline \multicolumn{8}{|c|}{ Health Risk(food insecurity, morbidity and mortality) } \\
\hline \multicolumn{2}{|c|}{$\begin{array}{l}\text { Lack of access to potable } \\
\text { water }\end{array}$} & $\begin{array}{l}\text { Lack of access } \\
\text { to safe sewerage }\end{array}$ & \multicolumn{2}{|c|}{$\begin{array}{l}\text { Lack of Solid waste } \\
\text { management }\end{array}$} & & $\begin{array}{l}\text { Stress and } \\
\text { anxiety }\end{array}$ & $\begin{array}{l}\text { Issue of } \\
\text { alcoholism }\end{array}$ \\
\hline \multicolumn{8}{|c|}{ Loss of access to common resourcesor higher order community facilities } \\
\hline \multicolumn{2}{|c|}{ Access to education service } & \multicolumn{3}{|c|}{ Access to health services } & \multicolumn{3}{|c|}{$\begin{array}{c}\text { Access to Market place, Fair Price } \\
\text { Shops offering PublicDistribution } \\
\text { System }\end{array}$} \\
\hline \multicolumn{8}{|c|}{ Social Disarticulation } \\
\hline \multicolumn{2}{|c|}{$\begin{array}{c}\text { Fragmentation of social } \\
\text { networks }\end{array}$} & $\begin{array}{c}\text { Loss of } \\
\text { kinship ties }\end{array}$ & \multicolumn{2}{|c|}{$\begin{array}{l}\text { Loss of community } \\
\text { institutions }\end{array}$} & \multicolumn{3}{|c|}{ Loss of cohesion in family structure } \\
\hline
\end{tabular}

\section{Assessment of off-site and on site resettlement projects, Indore.}

This section discusses emperical findings established under Cernea's (2000a) framework to examine impoverishment. It also presents the influence as well as interdependance of parameters of impoverishment and presents the gap between policy rhetoric and reality of practice by the local government in the two BSUP projects.

\section{Process rhetoric followed by local govt for relocation and resettlement under BSUP}

The procedure adopted for relocating and resettling the slum dwellers should be inclusive and should not create a situation of uncertainity and insecurity but the present procedure [Figure 2] has certain flaws which have evidently enhanced the perception of risk among the slum dwellers. 
Figure 2: Baseline process of relocation and rehabilitation of slum dwellers under BSUP ${ }^{8}$

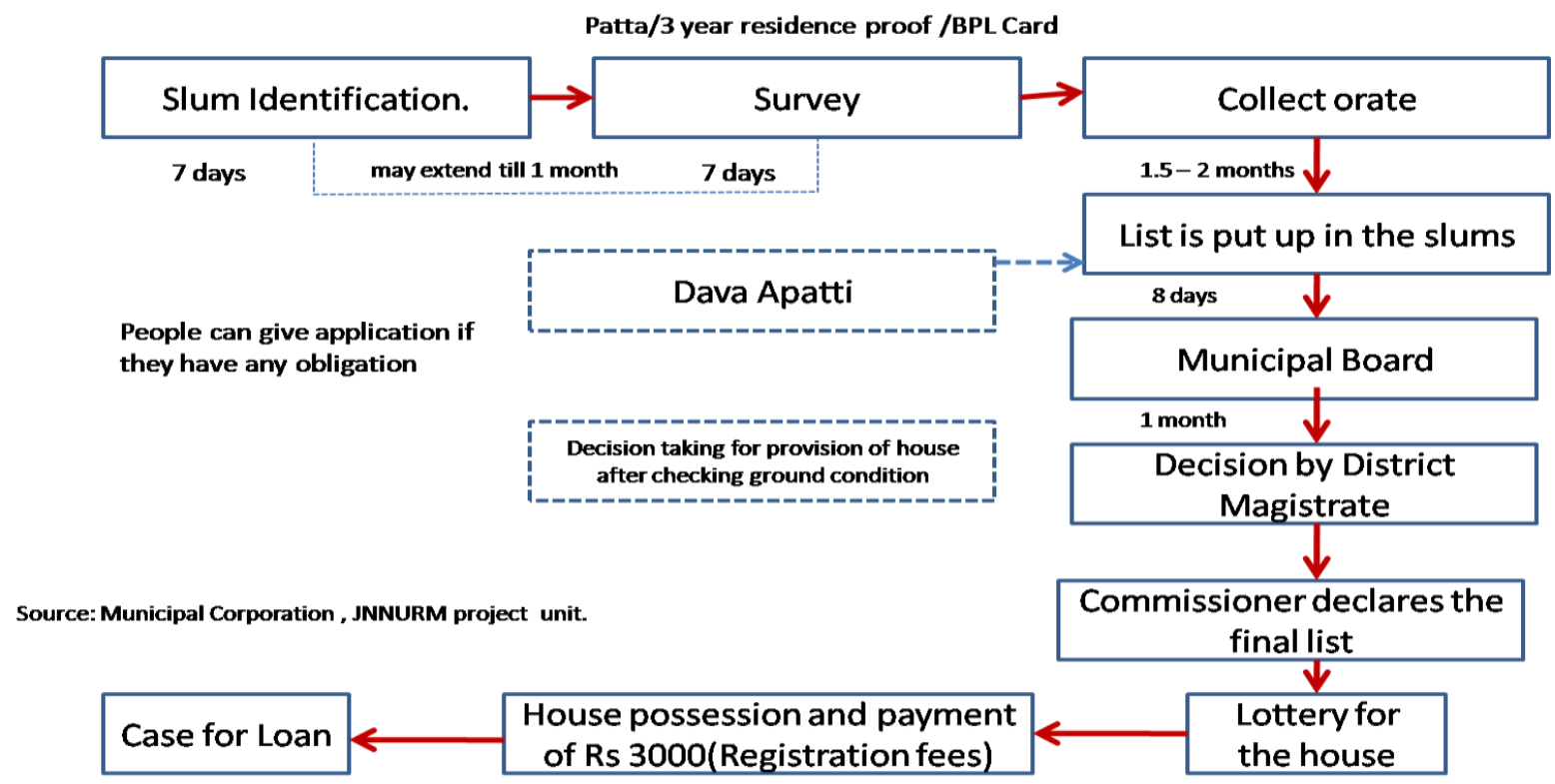

The procedure starts with identification of the slum to be evictedwhich takes between seven days and one month. Then the survey of the slum dwellers is done and their elegibility for entitlements post eviction is verified based on the availability of listed documents with them. The documents include the patta(below poverty line) (BPL) card, ration card and three years' proof of residence. Showing any one of the these documents, would make the slum dweller eligible to receive a dwelling unit at the resettlement site. The list of the surveyed slum dwellers is then sent to the collectorate and is finalised tentatively within two months. The list after being finalised is displayed in the slums for eight days and objections are invited through appeal to the municipal corporation. The municipal board makes changes to the list if they are required, and finally the Commissioner declares the final list. Eviction notice is then issued to the slum dwellers.

According to the respondents of this study, there was much uncertainity prior to the actual eviction as also found by the lead author in Ahmedabad case study (Patel, et al., 2013). For some households, notices were issued three months pior to the demolition but this duration varied considerably and in many cases slum dwellers received notice one day before the demolition. Twelve percent of the households interviewed for this study received an evacuation notice only one day before the demolition. Such an inconsistant approach of the Indore Municipal Corporation (IMC) stimulated a feeling of division and distrust among the slum community towards the local government.

${ }^{8}$ Source: Project Coordinator, JNNURM Project Office, Indore 
The inconsistancyof the IMC processes continued in the decision-making onwhich households were 'eligible' for the allocation of a dwelling unit. In the case of on-site resettlement, the admissible eligibility documents were the BPL card, ration card and the proof of three yearsresidence. IMC stated that the households with any one of these documents would be eligible for the allocation, but our survey indicates that only $56 \%$ of resettled households possesed one of the three documents. On the other hand $44 \%$ of the households on demolished slum sites possessed one or more of the eligibilty documents but they were not allotted a dwelling unit, and continued residing nearby as there was shortage of BSUP units. New units were proposed, but it was not certain at the time of the research that these households will be resettled despite possessing eligibility documents. The households which were allotted houses in Panchsheel Nagar, prior to their eviction, had to live on an interim site for almost three years and thus in this three-site process of being displaced from slum to interim site to the final site, the displacees lost their income, assets and social capital twice over.

In case of off-site resettlement at Scheme no. 134, the households which possesed eligibilty documents were allotted the BSUP units but so were some of those who did not possesse the documents and were affected by the developmental projects under JNNURM. On one hand such a practice is beneficial for slum dwellers as those who did not possess the eligibilty documents could not have accessed the formal markets for a housing loan in the absence of requisite formal documents. On the other hand however, this aggravates the process of illegal acquisition of BSUP dwelling units which further creates shortage of dwelling units for those who have been affected under the developmental projects and are actually 'eligible'.

\section{Discussions on each impoverishment risk}

\section{Landlessness}

The role of land varies in the context of urban and rural displacement. While in rural context land is the principal foundation for livelihood and productive systems with the loss of land leading to loss of principle livelihoods, in urban context, the significance of land is measured by its location. Consequently when households are relocated to distant off-site locations then their livelihood and quality of life is adversely affected. In Indore the urban poor were relocated due to developmental projects under JNNURM and, contrary to the claims inthe Detailed Project Report (DPR) for Scheme no. 134, no household has been resettled within a distance of 1.5 to 3 kilometers. In fact slum households have been resettled at an average distance of 8 kilometers [Figure 3] from eight of the sites: Kabirkhedi, Niranjanpur, Ishwar Nagar, Slums near Satya Sai Chowraha, Arvindo, Bhawarkua Chowraha, Piplihana tal, Anoop Talkies. 
Relocation ledto chronicunemployment of , 8.7\% workers while those who continued, had to travel on an average 8 kilometers to their workplace due to which their cost of travel to work increased by $405 \%$ andthe distance to work place increased by $214 \%$ vis a visthe departure slum. About $50 \%$ of workers were compelled toshift from non-motorised travel or public transport to motorised or private transport because of inadequte access to public transport on the new site [Table 3]. The $8.7 \%$ workers who lost their livelihoods, cited 'increased distance to previous place of work and inaffordability to travel there in absence of adequate public transport access on new site'as the principal reason for loss of livelihood.

The distance to school increased by an average of 3 kilometers or $220 \%$ [ Table 4] vis a vis the departure slum, and accessibility to public hospitals decreased as the distance to a public hospital increased by an average of 5 kilometers or $325 \%$ compared tothe departure slum.

Figure3: Map showing relocation distances to Scheme No. 134

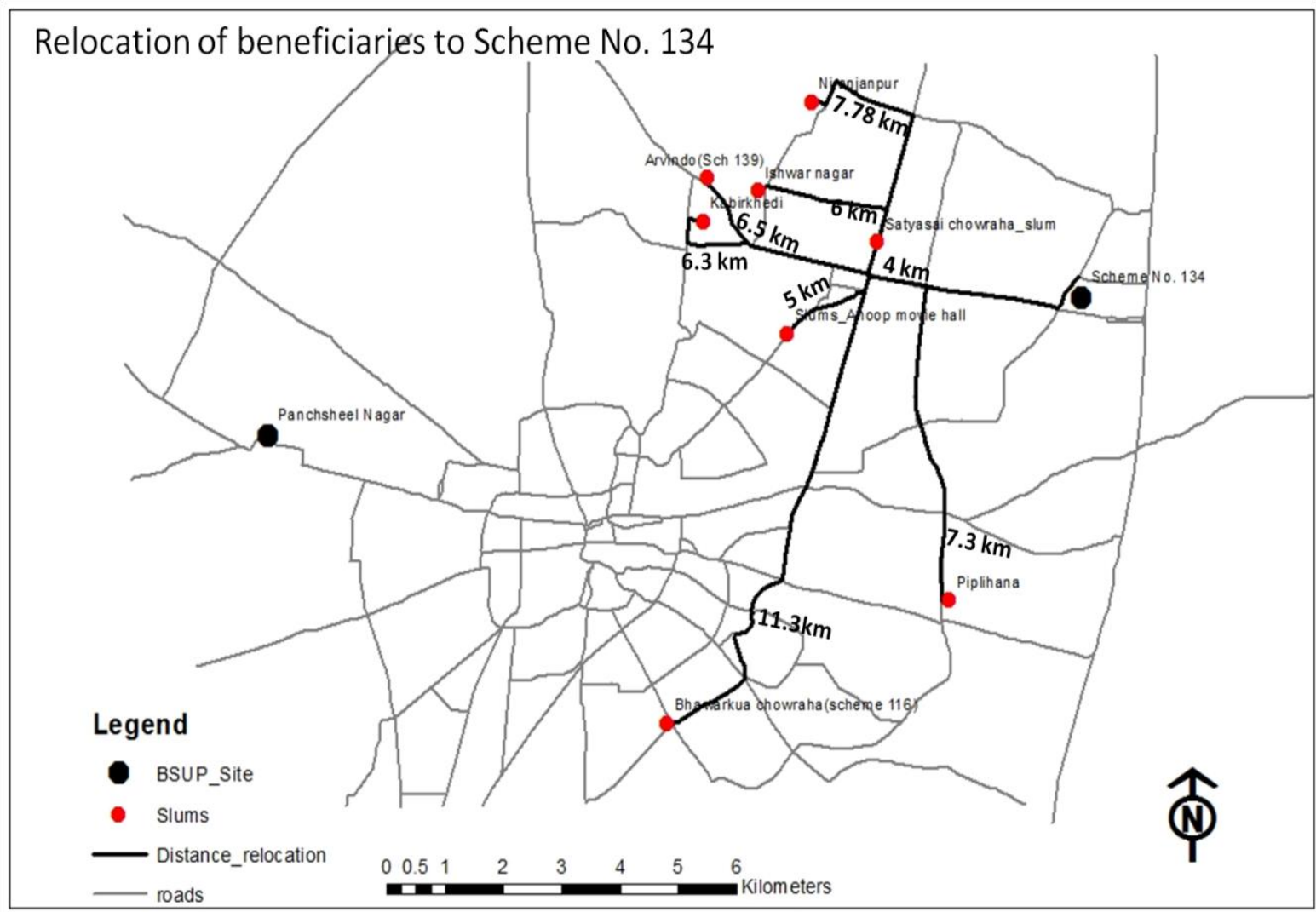


Table 3:Increase in distance to work and travel to work expenditure after resettlement

\begin{tabular}{|l|l|l|l|l|l|}
\hline & $\begin{array}{l}\text { Distance to Work } \\
\text { Place_Previous(Mea } \\
\mathrm{n} \text { distance in Km) }\end{array}$ & $\begin{array}{l}\text { Distance to } \\
\text { Work Place } \\
\text { current (in Km }\end{array}$ & $\begin{array}{l}\text { Average } \\
\text { increase in } \\
\text { distance to work } \\
(\mathrm{Km})\end{array}$ & $\begin{array}{l}\text { \% worktripsshiftedto } \\
\text { Public and motorised } \\
\text { mode of transport }\end{array}$ & $\begin{array}{l}\% \text { increase } \\
\text { in travel } \\
\text { expenditure } \\
\text { to work }\end{array}$ \\
\hline $\begin{array}{l}\text { Scheme No. 134 } \\
\text { (Relocation) }\end{array}$ & $2.8 \mathrm{Km}$ & 9 & $214 \%$ & $50 \%$ & $405 \%$ \\
\hline
\end{tabular}

Table 4: \% increase in distance to services from the relocation site to the departure slum site

\begin{tabular}{|l|l|l|l|l|l|}
\hline $\begin{array}{l}\text { Average increase } \\
\text { in distance to } \\
\text { school }(\mathrm{km})\end{array}$ & $\begin{array}{l}\text { \% increase in } \\
\text { distance to schoolw.r.t } \\
\text { departure slum site }\end{array}$ & $\begin{array}{l}\text { Average increase } \\
\text { in distance to } \\
\text { Health Centre } \\
(\mathrm{Km})\end{array}$ & $\begin{array}{l}\text { \% increase in } \\
\text { distance to Health } \\
\text { Centrew.r.t } \\
\text { departure slum site }\end{array}$ & $\begin{array}{l}\text { Average increase } \\
\text { in distance to } \\
\text { Market Centre } \\
(\mathrm{km})\end{array}$ & $\begin{array}{l}\text { \% increase in } \\
\text { distance to Market } \\
\text { Centrew.r.t } \\
\text { departure slum site }\end{array}$ \\
\hline 3 & $216.6 \%$ & 5.1 & $325 \%$ & 5.7 & $504 \%$ \\
\hline
\end{tabular}

This is corroborated by a respondent from Scheme no. 134 who states[Interview A, 8/04/13] 'I have lost my job due to relocation and our family was informed one day prior to the demolition of the house.The Municipal Officer did not listen to my request and my house was demolished. I registered a case regarding the losses and injustice done to me but no action has been taken yet'.

Those displacees who were resettled on-site within Panchsheel Nagar itself had to reside on an interim site which was 100 metres from the departure site. During the process of shifting to the interim house and then finally onto the newly constructed dwelling unit, not a single worker lost employment. Onsite resettlement thus has benefits over off-site resettlement in terms of locational aspects as economic ties as well as social ties of the people are less affected. The key findings therefore from this research is that the distance of resettlement has major implications for displacees and that, for this reason,onsite is a preferred option to off-site resettlement.

\section{Joblessness}

Loss of income is a major problem resulting from displacement. The loss of income due to loss of job or to additional financial burden as a result of displacementreduces the ability of displacees to overcome other unforeseen losses. Loss of job and additional financial burden incurred due to relocation aggravates impoverishment of the displacees (Cernea, 2000a).

The survey conducted in Scheme No. 134 (the relocation site) shows that $8.7 \%$ of the total workers lost their jobs while those who continued with their previous jobs,had to travel on an average 8 kilometers to their workplace, which was an average increase of $214 \%$ vis a vis the departure slum.The findings show that additional financial burden due to higher expenditures on health, transport, or Equated Monthly Installment (EMI) has affected the condition of the displacees [Table 5]. A large percentage of the income was now consumed in paying theEMI,electricity, transport and medical costs [Figures 4 and 5] which demonstratesthe increase in expenditure and reduction in savings, that will further trap the displacees into a cycle of poverty. 
In case of in situ resettlement the additional financial burden on the households was lower [Figs 6\& 7] as compared to households in the off-site resettlement area but it still affected their condition. In Panchsheel Nagar the displacees were moved to an interim site and then to the final site.Thus they had to incur the cost of upgrading their dwellings twice which increased their financial burden [Table 6].

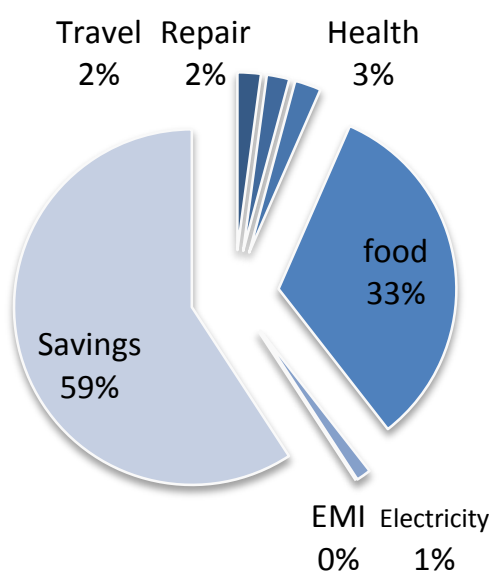

Figure 4:Monthly expenditure on servicespercentage share of income (relocation-previous)

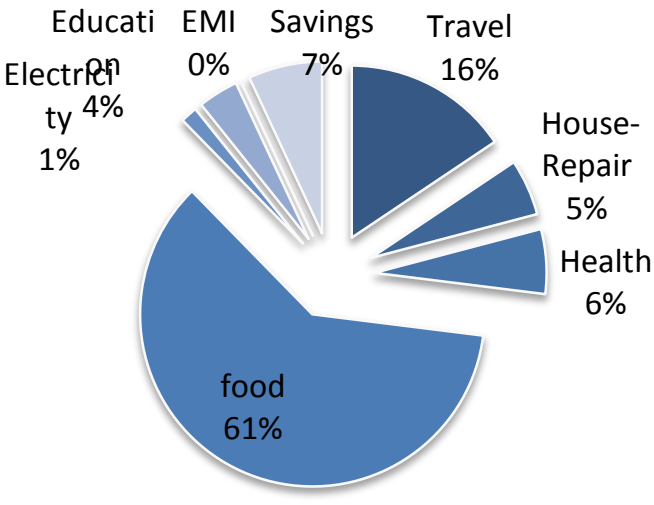

Figure 6:Monthly expenditure on servicespercentage share of income (insitu resettlementprevious)

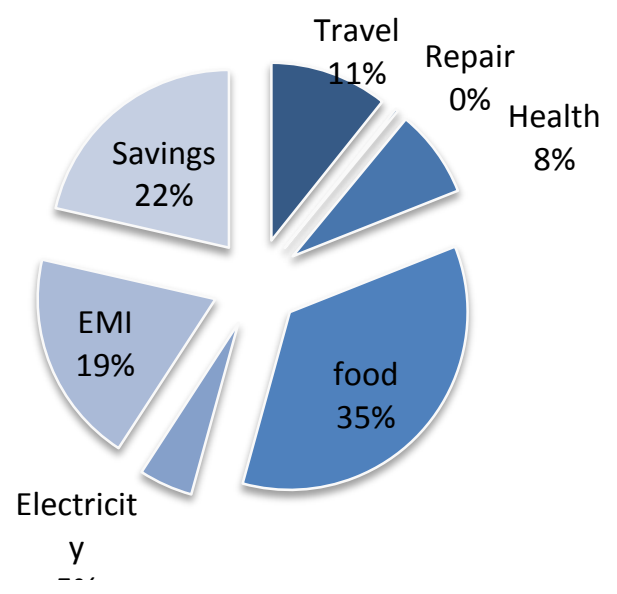

Figure 5:Monthly expenditure on services- percentage share of income (relocation- current)

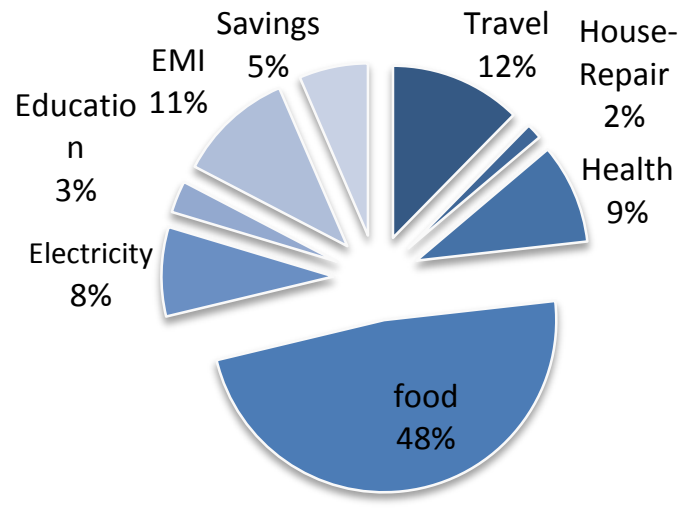

Figure 7:Monthly expenditure on services- percentage share of income (insitu resettlement-current)

\begin{tabular}{|l|c|c|c|c|c|c|c|}
\hline $\begin{array}{l}\text { Off site } \\
\text { Resettlement }\end{array}$ & $\begin{array}{c}\text { Travel } \\
\text { (INR) }\end{array}$ & $\begin{array}{c}\text { House } \\
\text { Repair } \\
\text { (INR) }\end{array}$ & $\begin{array}{c}\text { Health } \\
\text { (INR) }\end{array}$ & $\begin{array}{c}\text { Food } \\
\text { (INR) }\end{array}$ & $\begin{array}{c}\text { Electricity } \\
\text { (INR) }\end{array}$ & $\begin{array}{c}\text { EMI } \\
\text { (INR) }\end{array}$ & $\begin{array}{c}\text { Others } \\
\text { (INR) }\end{array}$ \\
\hline previous & 234 & 226 & 262 & 3619 & 147 & 0 & 6512 \\
\hline Current & 1180 & 28 & 881 & 3881 & 539 & 2134 & 2357 \\
\hline $\begin{array}{l}\text { Insitu } \\
\text { Resettlement }\end{array}$ & $\begin{array}{c}\text { Travel } \\
\text { (INR) }\end{array}$ & $\begin{array}{c}\text { House } \\
\text { Repair } \\
\text { (INR) }\end{array}$ & $\begin{array}{c}\text { Health } \\
\text { (INR }\end{array}$ & $\begin{array}{c}\text { Food } \\
\text { (INR) }\end{array}$ & $\begin{array}{c}\text { Electricity } \\
\text { (INR) }\end{array}$ & $\begin{array}{c}\text { EMI } \\
\text { (INR) }\end{array}$ & $\begin{array}{c}\text { Others } \\
\text { (INR) }\end{array}$ \\
\hline previous & 1135 & 385 & 442 & 4415 & 115 & 0 & 505 \\
\hline Current & 1135 & 135 & 864 & 4415 & 770 & 1000 & 595 \\
\hline
\end{tabular}

Table5: Monthly expenditure pattern after resettlement (in INR) 


\section{Homelessness}

Loss of one's home and of the group's cultural space leads to alienation, status deprivation and impoverishment(Cernea, 2000b). In Indore homelessness could be redefined by the households that have endured a long stay at the interim site in temporary, make-shift dwellings, and the households who continued to reside in the slums post-demolition as they were excluded from the resettlement package.

The households who resided on the interim site for three years (in the case of PanchsheelNagar) had to construct a new house at their own cost, as the compensation offered by IMC was meagre. They were offered only a plot of $10 \mathrm{ft}$ x $10 \mathrm{ftand}$ a few logs for constructing the house. The survey shows that most households at the interim site resided in dwellings with temporary structures which were both unsafe and unhygienic, while $46 \%$ of the same households had permanent dwellings in the departure slum.

The displacees on an average had lived for 25 years in their departure slum and over many they had substantially developed the dwelling unit. Resettlement caused them to lose these assets and also incur economic costs for shifting the assets and reconstructing another house at the interim site. The average cost of upgrading on an interim site per household was INR 27,394 [Table 6]. To overcome this cost they had to either use their savings or incurr debts which further led them towards impoverishment. The interim site had inadequate provision of sewerage, drainage and solid waste disposal facilities which made the site almost unhabitable. After three years the displacees were once again relocated to newly constructed BSUP units. In this whole cycle of relocation,the displacees were pushed towards impoverishment as their housewas demolished twice and the average loss of assets during the demolition at the interim site was INR 22,363. The total loss thus amountedan average of INR 49,757.

The displacees in the off-site resettlement site earlier had houses with permanent structures [Table 6] and $27 \%$ of the household had individual water connection. Displacement and resettlement caused them to suffer loss of INR 30,956 due to demolition[Figure 8], and to bear the additional costs of transporting the assets to the new dwelling unit[Figure 9]. These slum dwellers were living in the departure slum sites for an average of 25 years and during this period they had developed social and cultural capital in the neighbourhood. Thus with displacement and loss of shelter they were deprived of their economic, social and cultural well being as a result of which social impoverishment had set in.

Table 6: Associated losses for displacees while relocation and in situ resettlement

\begin{tabular}{|l|c|c|c|c|c|c|}
\hline Site & $\begin{array}{c}\text { \% households with } \\
\text { permanent and semi- } \\
\text { permanent houses in } \\
\text { departure slum }\end{array}$ & $\begin{array}{c}\text { \% households } \\
\text { with individual } \\
\text { water connection } \\
\text { in departure slum }\end{array}$ & $\begin{array}{c}\text { Average } \\
\text { Value of } \\
\text { lost assets } \\
\text { (INR) }\end{array}$ & $\begin{array}{c}\text { Average } \\
\text { Cost of } \\
\text { transporting } \\
\text { assets (INR) }\end{array}$ & $\begin{array}{c}\text { Average } \\
\text { Cost of } \\
\text { upgrading } \\
\text { on new } \\
\text { site (INR) }\end{array}$ & $\begin{array}{c}\text { Average } \\
\text { total Cost } \\
\text { (INR) }\end{array}$ \\
\hline $\begin{array}{l}\text { Panchsheel Nagar } \\
\text { (Insitu Rehabilitation) }\end{array}$ & $46 \%$ & $2 \%$ & 22,363 & Nil & 27,394 & 49,757 \\
\hline $\begin{array}{l}\text { Scheme No. 134 } \\
\text { (Relocation) }\end{array}$ & $61 \%$ & $27 \%$ & 30,956 & 1148 & 0 & 32,104 \\
\hline
\end{tabular}




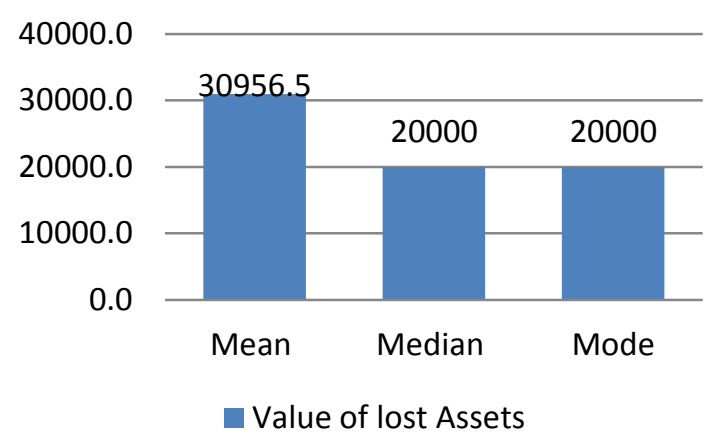

Figure 8:Value of lost assets - Scheme no. 134

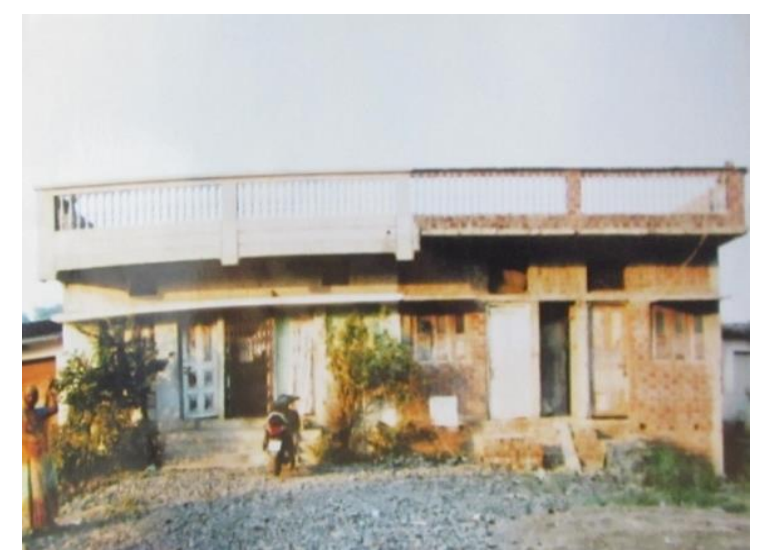

Figure 10:House of beneficiary before demolition

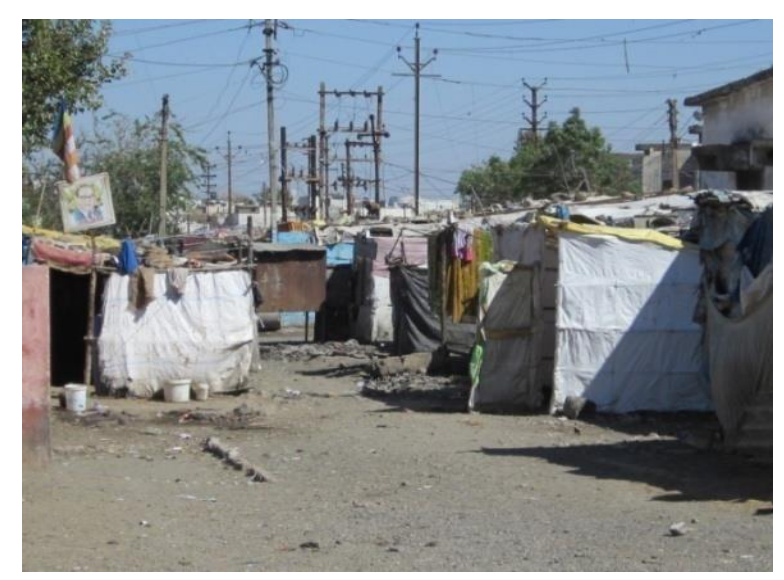

Figure 12: Interim site beforerehabilitation

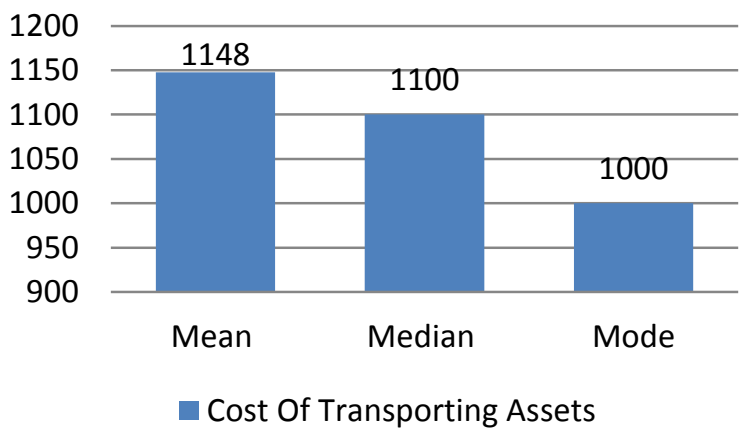

Figure 9:Cost of transporting assets- Scheme No. 134

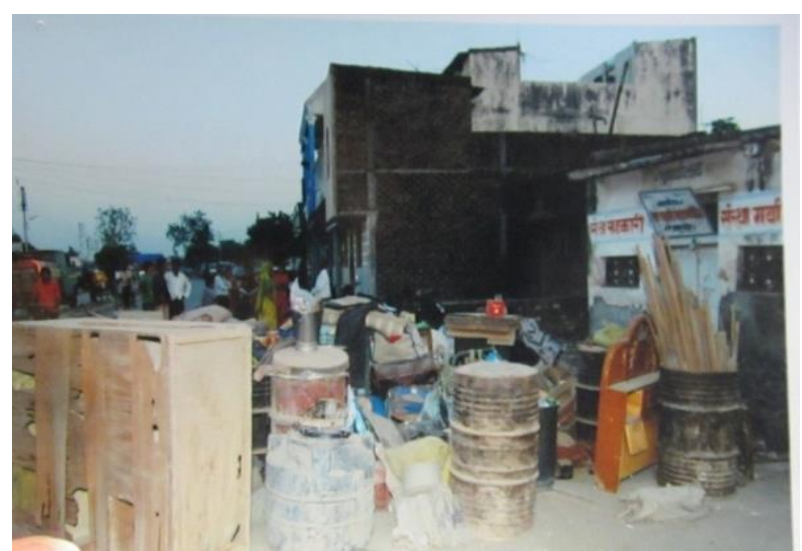

Figure 11:Loss of assets due to forceful eviction

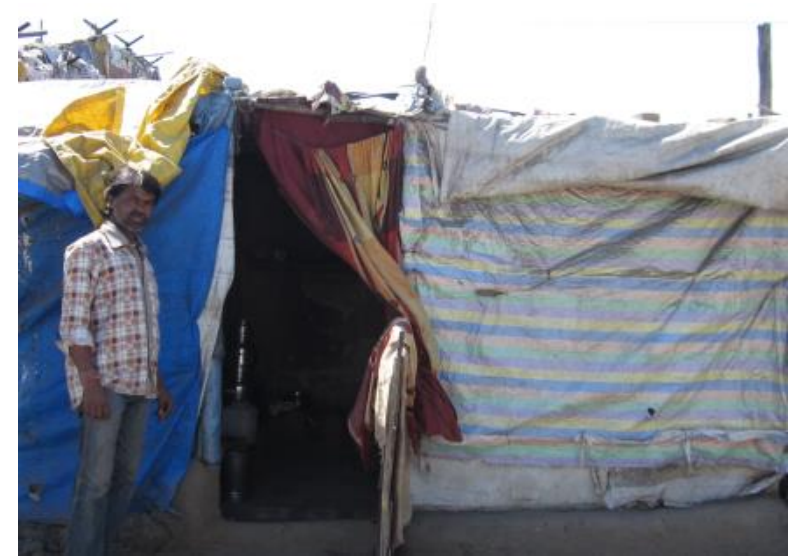

Figure 13: Dwelling unit at interim site 


\section{Marginalisation}

The risk of marginalisation threatens displaced individuals and their entire community as they slip into a relatively lower socio-economic status. Research has shown that such marginalisation is accompanied by a loss of self-esteem, especially when the displaced become 'outsiders' and 'newcomers' in the host communities (Downing, 2002).

Displacement induces marginalisation and the study found that in the resettlement site households from different slum sites were brought in, which fostered a sense of alienation among the slum dwellers, further leading to loss of standing in the community. Displacees were not happy with the different communities staying in the new site and there was a feeling of distrust among them. The feeling of marginalisation was corroborated by a displaced woman who stated[Interview B, 09/04/13] that 'I do not trust people from other communities here and men create nuisance during night.We have been forcefully evicted so we have to stay here in this locality though we do not feel secure'.

Slum dwellers displaced under JNNURM project and who had the requisite document to prove 'eligibility' such as BPL or patta cards were allocated BSUP units on the resettlement site, but some of those who did not have either of the documents and were officially 'not eligible'were also allotted dwelling units. Provision of dwelling units to those who did not possess legal documents was on one hand beneficial because they were also evicted by the development projects and did not have access to a formal market housing loan, in the absence of collateral documents. On the other hand, this precedent gave rise to illegal acquisition of dwelling units and deprived those who were actually 'eligible' and needed shelter post-eviction. Consequently this often led to conflicts between the two groups. Those who had the legal documents possessed a grudge towards those who did not as they perceived the latter had deprived their kin from access to dwelling units in this site as the units were limited and less than the number of claimants. Due to these factors, we observed a strong sense of marginalisation and communal divide within the resettlement site.

\section{Health risks}

Health risks on new resettlement -sites arise due to various factors such as poor access to safe drinking water, poor access to sanitation facilities, inadequate solid waste management, stress and anxiety as well asrestricted or no access to fair price shops (FPS) or the public distribution system which gives subsidised food rations to BPL card holders, leading to malnutrition (Patel, et al., 2013). In Panchsheel Nagar solid waste was dumped on open sites; $57 \%$ of the respondents disposed of solid waste on open sites and $41 \%$ reported irregular clearing of solid waste by the local government, which led to poor hygiene and increased incidences of related diseases. Water was supplied only twice a week and then for an average of only one hour. Such limited water supply was found to severely challenge the health and hygiene of the residents. Newly constructed sewerage facilities were already falling apart, and $48 \%$ of the displacees were dissatisfied with the sewerage network as it was choked and overflowing. 
In the resettlement -site, all respondents (100\%) disposed of solid waste on open spaces on the site and the municipal dustbins were not cleared on regular basis by IMC, creatingan unhygienic environment leading to breeding of insects and mosquitoes. As a consequence of all these factors, about $33 \%$ of the households reported to have suffered from malaria and/or typhoid over the year. Consequently expenditure on illness treatment [Table 5] has increased tremendously on both sites, in terms of both the total amount and the percentage of monthly income. On the relocation-site, health expenditure per household as percentage of monthly income has increased from 3\% in the departure slum to $8 \%$, whereas in the on-site case it has increased from $6 \%$ to $9 \%$ post-resettlement. In absolute value the monthly health expenditure had more than doubled on both the sites[Table 5].

The study shows a marked increase in the incidence of alcoholism in the case of the relocation-site where $96 \%$ of the respondents reported to have faced problems related to alcoholism either within the household or from the community. Most households cited anxiety and stress related to relocation issues as the principal reasons of high alcoholism within the community. Emphasising the sense of insecurity emanating from alcoholism, a woman from Scheme no. 134 [Interview C, 09/04/13] statedthat 'Streets lights are non-functional, it is completely dark at night and it becomes unsafe for women and children to walk during night or even pass through this location. People after drinking cause menace during night and make the place unsafe to live in'. Furthermore the distance to marketplace with FPS or public distribution shops increased by 5.7 kilometers (504\%) leading the households to involuntarily fall into malnourishment as they were forced to buy their staple food at the market price while earlier they could access goods from the ration shops in the vicinity at a highly subsidisedrate. Due to the additional financial burdens and joblessness, households were found to compromise their essential food intake leading to cases of malnourishment in many households.

\section{Loss of access to community facilities}

For human wellbeing in urban areas, it is necessary to have access to community facilities such as schools, health centers, hospitals, ration shops, market places, etc. The study shows that, contrary to the claims made made in the Detailed Project Report for Scheme no.134, primary schools or health centers have not been constructed [Table 7]. The facilities that exist near the site are too expensive, making it unaffordable for the displacees to access them. In the case of on-site resettlement site Panchsheel Nagar there is a primary school and primary health center in its proximity. The primary health centre only provides basic health care services but does not attend to medical emergencies which can be catered to only by higher order services such as hospitals which are a distance from the site. Consequently, on the off-site resettlement site, $13 \%$ of students dropped out of school. The residents cited increased distance to public schools and inadequate access to public transport as major reasons. The average distance to school increased by 3 kilometers or $217 \%$ vis-a-vis the departure site. Similarly, due to relocation the distance to the public health services increased by 5 kilometers or $325 \%$ compared to the departure site which resulted in inaccessibility to the health services during emergencies. 


\begin{tabular}{|l|l|l|l|l|l|l|l|}
\hline BSUP Site & $\begin{array}{l}\text { Any } \\
\text { Welfare } \\
\text { Assoc } \\
\text { Formed }\end{array}$ & $\begin{array}{l}\text { Primary } \\
\text { Health Centre } \\
\text { Constructed }\end{array}$ & $\begin{array}{l}\text { Primary } \\
\text { Health } \\
\text { Centre } \\
\text { Functioning }\end{array}$ & $\begin{array}{l}\text { Primary } \\
\text { school } \\
\text { Constructed }\end{array}$ & $\begin{array}{l}\text { Primary } \\
\text { School } \\
\text { Functioning }\end{array}$ & $\begin{array}{l}\text { Community } \\
\text { Hall/space }\end{array}$ & $\begin{array}{l}\text { Park/ } \\
\text { Garden }\end{array}$ \\
\hline Scheme No. 134 & No & No & No & No & No & Yes & No \\
\hline Panchsheel Nagar & No & Yes (nearby) & Yes & Yes (nearby) & yes & yes & No \\
\hline
\end{tabular}

Table 7: Status of community facilities on BSUP sites

Deficient health services, poor on-site conditions and poor hygiene led to increase in incidences of diseases and resultant morbidity as discussed above. As a consequence of poor health the economic productivity of households has gone down leading to a state of impoverishment.

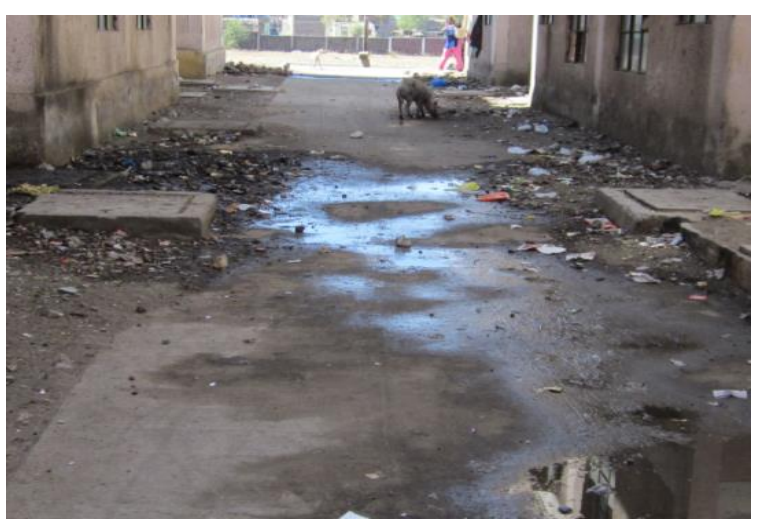

Figure 16: Unhygenic conditions at in situ resettlement site

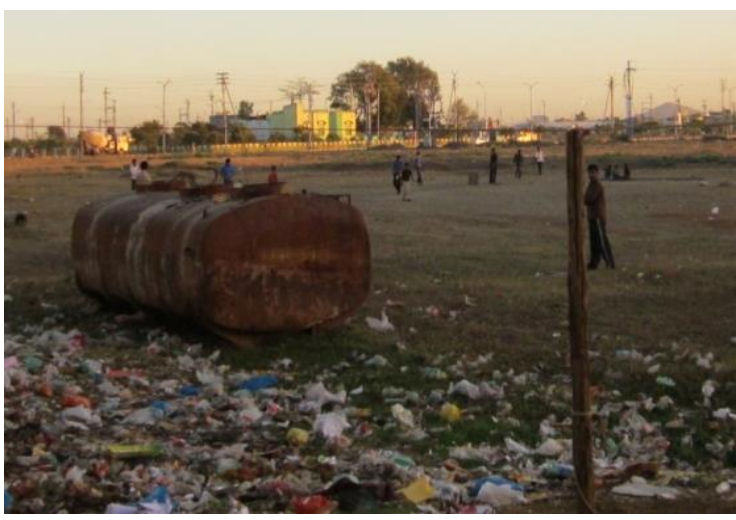

Fig 14: Unhygenic conditions at the relocated Site

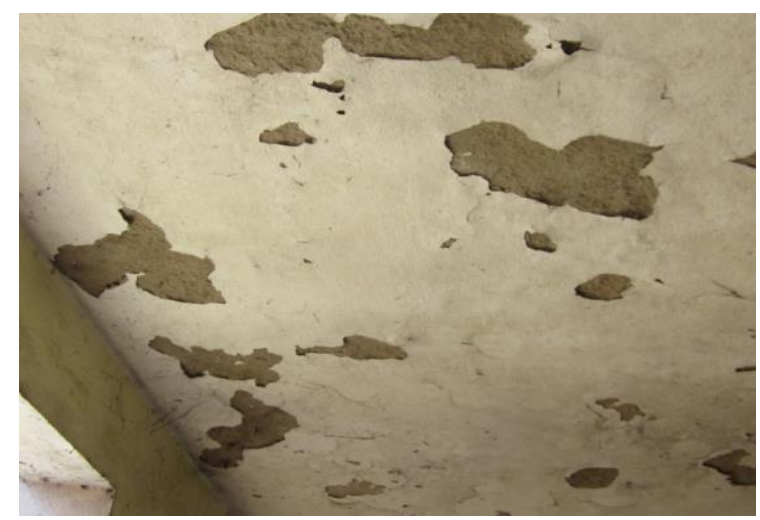

Figure17: Construction failure in insitu resettlement site

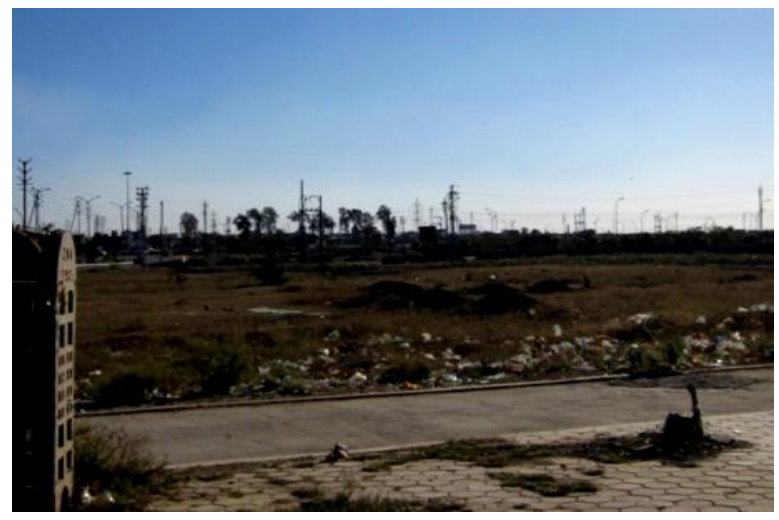

Fig 15:Location of Relocated site in a secluded area 
Figure 18: Map showing location of major hospitals and distance from relocation and insitu rehabilitation site

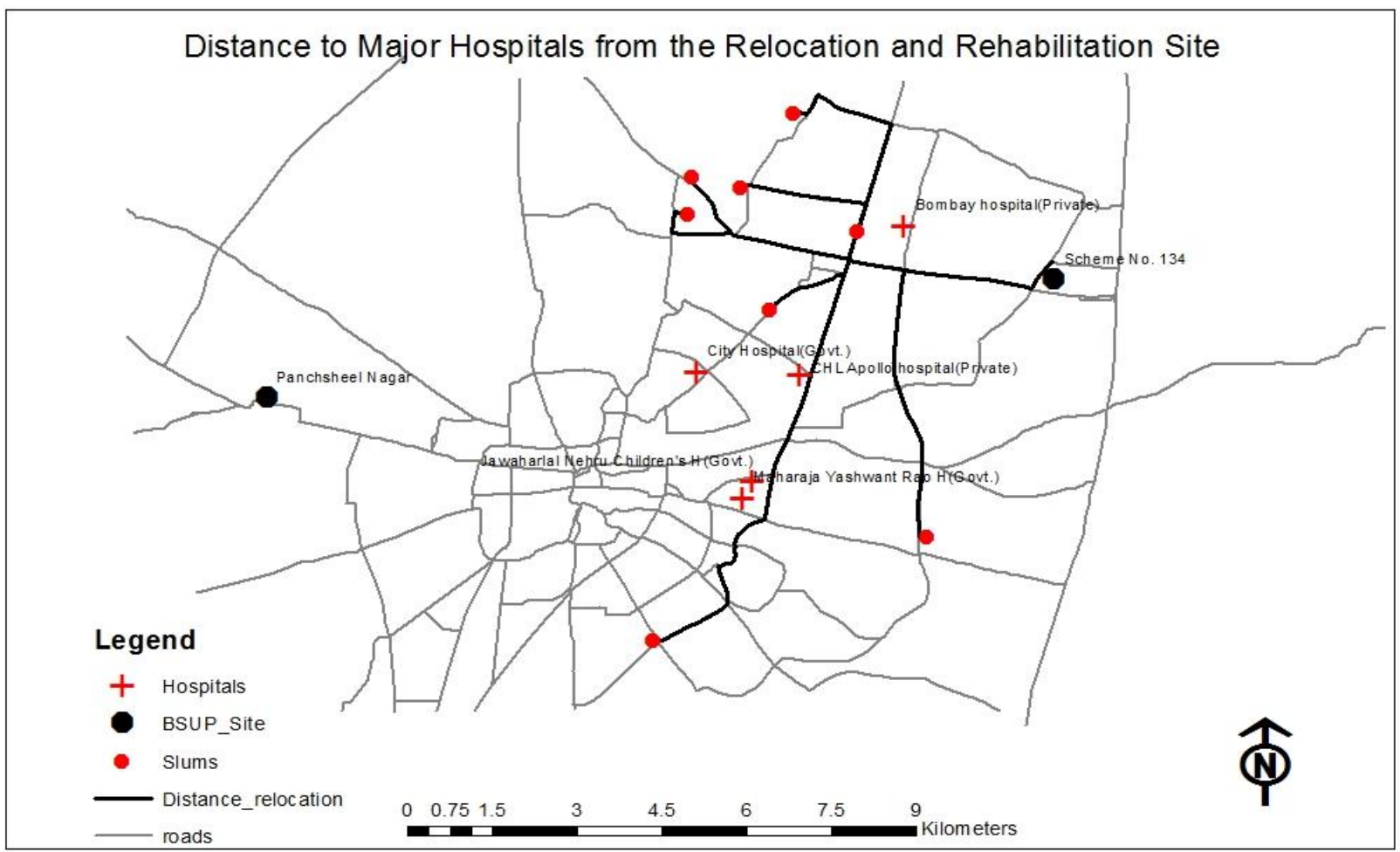

\begin{tabular}{|c|c|c|c|c|c|}
\hline BSUP site & $\begin{array}{l}\text { Maharaja } \\
\text { Yashwant (Govt.) } \\
\text { (in km) }\end{array}$ & $\begin{array}{l}\text { Jawaharlal Nehru Children's } \\
\text { H. (Govt.) (in Km) }\end{array}$ & $\begin{array}{l}\text { CityH } \\
\text { (Govt.) } \\
\text { (in Km) }\end{array}$ & $\begin{array}{l}\text { CHL Apollo H } \\
\text { (Private) (in Km) }\end{array}$ & $\begin{array}{l}\text { Bombay H } \\
\text { (Private) (in } \\
\text { km) }\end{array}$ \\
\hline Scheme No.134 & 8.7 & 8 & 7 & 5.5 & 3.25 \\
\hline Panchsheel Nagar & 8 & 8.5 & 8.5 & 10.5 & 14 \\
\hline
\end{tabular}

Table 8: Distance to major hospitals in the city form relocation and insitu resettlement sites 


\section{Social disarticulation}

Displacement fragments the social fabric of a community including its spatial and cultural determinants(Cernea, 2000b; Downing, 1996).As kinship groups become scattered, the capacity for collective action, voluntary associations and mutual help groups are disrupted. Cernea (2000a) terms this as net loss of social capital which compounds the loss of natural, physical and human capital discussedearlier. When the resettled families find themselves new to the environment, neighbourhood, and jobs, they tend to feel isolated and disordered or socially disarticulated. Further it tends to lead to instablilty, insecurity and unpredictability in daily life, leading to reduced health and wellbeing. Social disarticulation is interlinked with health risks and marginalisation and so deterioration of one may lead to the worsening of the other. Hence it needs to be addressed in the resettlement policies (Downing \& Garcia-Downing, 2008).

The findings show that displacees from eight different slums were resettled on the off-site relocation site and were resettled in a dispersed manner. Also from each of the slum site, only a fragment of the community was resettled on this site, whilst the others from the community were resettled on other sites. As many small fragments of communities were resettled, social disarticulation and its factors could be strongly observed. In such a case the participation by displacees in maintaining urban services and community resources on-site was completely absent. From the interviews it emerged that the displacees were alienated from and dissatisfied with other residents and they had a feeling of distrust among them. The harmony which was present in the communities at the departure site was entirely missing in the new site. The communities which earlier used to maintain common property resources now have to depend on external sources such as IMC or NGO's for operation and maintenance of those resources.

The situation was better in case of on-site resettlement as the same community structure was maintained which helped in preserving the social networks but the displacees were subjected to other risks such as kinship scatteredness and lack of cohesion among families as the method of allotment of dwelling unit was through lottery, leading to uncoordinated placement and scattering of the families. About $21 \%$ of the respondents said that less than half of their kin were rehabilitated and those that were were scattered either across the same site or at a different site, aggravating the problem of social disarticulation. 


\section{Mitigating impoverishment risks due to off site and on site resettlement}

This study demonstrates the process and outcomes of displacement and resettlement due to urban development in Indore. An in-depth study of DIDR literature and detailed fieldwork was done to analyze the condition of households which were affected by the DIDR programmes. Based on the literature review and by redefining Cernea's impoverishment risks in the urban context, indicators were derived for studying the impacts of the DIDR programmes ofthe off-site and on-site resettled families. These parameters were landlessness, homelessness, joblessness, marginalisation, health risks (which included food insecurity and mortality), marginalisation, social disarticulation and loss of access to community resources or facilities. Our findings confirm the validity of Cernea's (2000b) impoverishment risks in the case of urban displacements as all forms of impoverishment have been experienced amongst the displacees, contributing to their overall impoverishment. The findings from this study validate similar research undertaken in Ahmedabad, Gujarat(Patel, et al., 2013)about Cernea's impoverishment risks in displacees.

Our findings clearly show the link between various impoverishment forms, but indicate that 'landlessness' - or rather in the urban context 'relocation distance' - is the most important cause of post-displacement impoverishment. As in the case of Ahmedabad (ibid), our research in Indore shows that most of the forms of impoverishment such as joblessness, lack of access to community facilities, health risks, food insecurity, and social disarticulation, are derivatives of the displacement distance. An increased distance to workplace, health centres, market place, ration shops and community facilities has compunded the vulnerability of the displacees pushing them into poverty. A comparison between the residents of off-site and on-site resettlements in the study clearly indicates that in all of these aspects, the respondentsresettledon-site, though showing evidence of vulnerability themselves, were better off than the those who were relocated off-site. The relocation distance thus emerges as the most critical component in urban DIDR and must be adequately addressed in all DIDR related policies.

A review of the BSUP guidelines formulated by the Government of India indicates that some aspects of impoverishment risks - such as landlessness, joblessness, homelessness, access to community facilities, health risks, social disarticulation and economic marginalisation - are only partially addressed in BSUPpolicy rhetoric and guidelines, as the programme was not primarily meant to be a housing rehabilitation programme.Furthermore, there is a cleargap between the BSUP policy rhetoric and actual practice by local government.

Moreover, other risks such as food insecurity and social marginalisation are completely absent in the BSUP policy rhetoric. For instance, though the BSUP guidelines and appraisal checklist indicates that on-site resettlement is preffered, in Indore out of the 12 approved projects, only two were cases of on-site resettlement whereas ten were of off-site relocation. 
Though the BSUP guidelines indicate that in the case of off-site relocation, it should bepreferablywithin same municipal ward or within three kms radius, we have shown that in case of Indore's off-site relocation-site, the average distance of relocation was 8 kilometers.Impoverishment due to DIDR in Indore is characterised by limited attention to these issues both in the BSUP policy rhetoric, and in the practices of the local government. The negative impacts of DIDR could be mitigated and livelihoods of the displacees could be restored if all the potential impoverishment risks are identified prior to policy formulation and some critical measures are taken by local government.

These measure could include:

Community Participation as 'Partnership' or 'Delegated power': Community participation is fundamental in the formulation of DIDR policy. However the nature of community participation must not be in the current form as practicsed by local government in Indore i.e. tokenism under which the community is heard in a 'stakeholder workshop' but is empowered with no decision-making ablities. Instead it should be formalised in the nature of 'partnership' enabling them to negotiate and engage in trade-offs with local governmentover critical factors such as location, affordability and willingness to pay housing installments etc.

Preference for on-site reseetlement or near site relocation: Relocation to far-off sites deepens the impoverishment of slum displacees.As per BSUP guidelines, on-siteresettlementshould be the norm and only if absolutely imperative, off-site relocation should be preferred but within the same municipal ward,and with adequate and enhanced attention to maintaining social capital and rebuilding community facilites, transportation links and appropriate employment opportunities.

Social considerations: Findings from the case studies clearly indicate that social parameters such the extent to which kinship networks are scattered, community space, safety and security, and marginalisation and alcoholism, play a significant role in the impoverishment of displacees. Instead of one slum community being scaterred over many resettlement sites as evident in the two focus case studies in this paper, such communities should be resettled in a single site. Additionally, instead of a lottery system for allocation of dwellings on a site, displacees should be allowed to choose their neighbours, enabling them to maintain socialties and kinship networks. Simple provisions such as these in the policy can avert many ills related to social disarticulation.

Livelihood Restoration and Capacity building: DIDR causes significant loss of assets and livelihoods of the displacees. Therefore it is necessary to understand thoroughly the human, physical and social assets of the community before implementing BSUP projects. Provision of opportunities for employment of displacees on the site, or provision of opportunities for self-employment and incorporation of related skills development programmes in the scheme itself should be provided by local government to avert the risks of economic impoverishment of displacees. 
Reviewing and Monitoring: BSUP policy has a stringent provision and elaborate framework for reviewing and monitoring of project implementation. However the framework makes provision for review onlyof financial (grant utilisation) and physical (construction) progress made by local government. Review of social inclusion or a social audit has to be included to ensure that local government meaningfully engages and negotiates with the community in decision-making throughout the entire operative cycle of the project.

Social implementation unit or resident welfare association (RWA): Though not mandated in BSUP policy and guidelines, RWAs in BSUP sites have been implemented post-occupancy by some ULBs (e.g. Ahmedabad). This should be emulated in Indore by the city council so that social rearticulation can be achieved, issues around maintenance of common property resources and utilities can be resolved, and the community can self-govern itself and the site without dependance on external agencies.

\section{Conclusion}

Urban development and related displacement will be inevitable in the coming decades in rapidly urbanising India. Under JNNURM large scale urban development induced displacements of the poor have been witnessed across majority of themillion+ cities of India such as New Delhi, Hyderabad, Bangalore, Mumbai, Ahmedabad, Kolkatta, Indore etc. Some of the displaced, as in the case of Indore and Ahmedabad, are resettled under BSUP projects. Though the policy of BSUP was formulated by the Government of India's Ministry of Urban Development, Housing and Poverty Alleviation (MoUDH\&PA), the projects are implemented by local government, albeit under a review and monitoring mechanism of MoUDH\&PA. Limited attention is paid to various aspects of impoverishment risks of the displaced poor in the policy rhetoric, and especially in the implementation of projects by local governments. This paper has clearly shown the negative result of this apathy on the displaced urban poor, and especially the often devestating impact of an increased displacement distance resulting from off-site relocation. There are clear advantages for the urban poor of being resettled on- or near-site and more emipirical research from other cities, bothin India and across the Commonwealth will add to the growing arguement against unneccesary off-site displacement and for adequate mitigation measures within policies to prevent impoverishment of displacees. 


\section{References}

Bartolome, L. (1933). The Yacrela Experience with Urban Resettlement: Some Lessons and Insights. In M. Cernea, \& S. Guggentreim (Red.), Anthropoligical Approaches to Resettlement: Policy, Practice and Theory. Oxford: Westview Press, Boulder and San Fransisco.

Bhan, G. (2009). 'This is no longer the city I once knew':Evictions, the urban poor and the right to the city in millennial Delhi. In Environment and Urbanisation (Vol. 21(1), pp. 127-142).

CDP-Indore. (2006). City Development Plan- Indore. Indore: Indore Municipal Corporation.

Census. (2011). Indore City Census 2011 data. (Government of India) Census 2011: http://www.census2011.co.in/census/city/299-indore.htm

Centre for Development and Human Rights(CDHR). (2010). Rights and Development Bulletin (Vol. 1).

Cernea, M. (1996). Understanding and Preventing Impoverishment from Displacement. In C. McDowell (Red.), Understanding Impoverishment: The Consequences of Development Induced Displacement. Oxford: Berghahn Books.

Cernea, M. (2000a). Impoverishment or Social Justice? A Model for Planning Resettlement. In M. Cernea, H. M. Mathur, \& D. Marsden (Red.), Development Projects and Impoverishment Risks: Resttling ProjectAffected People in India (Vol. a). Oxford University Press.

Cernea, M. (2000b). Risks, Safeguards and Reconstruction: A model for Population Displacement and Resettlement. In M. Cernea, M. Cernea, \& C.McDowell (Red.), Risks and Reconstruction: Experiences of Resettlers and Refugees (Vol. b). Washington DC: The World Bank.

Cernea, M. (2006). Resettlement Management: Denying or Confronting Risks. In H. M. Mathur (Red.), Managing Resettlement in India: Approaches, Issues, Experiences. New Delhi: Oxford University Press.

Cernea, M. (2008). Compensation and benefit sharing: Why resettlement policies and practices must be reformed. In Water Science and Engineering (1 ed., Vol. 1, pp. 89-120). Washington DC.

Cernea, M., \& Kanbur, R. (2002). An Exchange on the Compensation Principle in Resettlement. Cornell University.

Downing, T. E. (1996). Mitigating Social Impoverishment when People are Involuntarily Displaced. In T. E. Downing, \& C. McDowell (Red.), Understanding Impoverishment Providence. Oxford: Berghahn Books.

Downing, T. (2002). Avoiding New Poverty:Mining Induced Displacement and Resettlement. IIED and World Business Council for Sustainable Development.

Downing, T. E. (2002). Avoiding New Poverty: Mining-Induced Displacement and Resettlement, Mining, Minerals and Sustainable Development.

Downing, T. E., \& Garcia-Downing, C. (2008). Routine and Dissonant Cultures. In A. Oliver-Smith (Red.), Development \& Dispossession: The Crisis of Forced Displacement and Resettlement. Santa Fe: SRA Press.

Gass, S. M., \& Mackey, A. (2013). Stimulated Recall Methodology in Second Language Research: Routledge.

Hoadley, M. (2004). Development-Induced Displacement and Resettlement-Impoverishment or Sustainable Development? Opgehaald van http://www.csmi.co.za/l/papers/Displacement_resettlement feb04.pdf

Interview A, 08/04/13. Vijay, Impoverishment Assessment of Slum Dwellers after in situ and off-site relocations: A case of Indore. (R. Mandhyan, Interviewer)

Interview B, 09/04/13. Jabaniso, Impoverishment Assessment of Slum Dwellers after in situ and off-site relocations: A case of Indore. (R. Mandhyan, Interviewer)

Interview C, 09/04/13. Asha, Impoverishment Assessment of Slum Dwellers after in situ and off-site relocations: A case of Indore. (R. Mandhyan, Interviewer)

Kabir, T. (2011). Factors affecting slum resettlement projects in Bangladesh:A case study of 'Bhasantek Rehabilitation Project', Dhak. Netherlends: Rotterdam.

Mehta \& Associates. (2006). DPR for Slum Rehabilitation Scheme at Scheme No. 134 Under JNNURM. Indore: Indore Development Authority. 
Moser, C. O. (1998). The Asset Vulnerability Framework: Reassessing Urban Poverty Reduction Strategies. In World Development (1 ed., Vol. 26, pp. 1-19).

Oliver-Smith. (2009). Development and Dispossession: The Crisis of Development Forced Displacement and Resettlement. In Oliver-Smith (Red.). Santa Fe and London: School for Advanced Research(SAR) Press and James Currey.

Patel, S., Sliuzas, R., Mathur, N., \& Miscione, G. (2013). Impoverishment risks in urban development induced displacements and resettlements inAhmedabad. Ahmedabad.

Restrepo, P. (2013). The tricky question of calling a slum a slum. Opgehaald van favelissues.com: http://favelissues.com/2012/04/02/the-tricky-question-of-calling-a-slum-a-slum/

Serageldin, I. (2006). Involuntary Resettlement in World Bank Financed Projects: Reducing Impoverishment Risks for the Affected People. In H. M. Mathur (Red.), Managing Resettlement in India: Approaches, Issues, Experiences. New Delhi: Oxford University Press.

UN-HABITAT. (2010). Count me in, Surveying for tenure security and urban land management, Global Land Tool Network(GLTN),United Nations Human Settlements Programme (UN-HABITAT), Kenya,2010

Wang, W. (2010). Rebuild a Home in Delhi- Towards Better Resettlement of Urban Poor. Lund University, Centre for East and South-East Asian Studies.

World Bank. (1994). Resettlement and Development 1989-1993. Washington: The World Bank. 